\title{
Uso de residuos de la industria del mármol como filler para la producción de hormigones autocompactantes
}

\section{Use of waste from the marble industry as filler for the production of self-compacting concretes}

\author{
P. Valdez $z^{(*)}$, B. Barragán ${ }^{(* *)}$, I. Girbes ${ }^{(* * *)}$, N. Shuttleworth(****) y A. Cockburn(****) \\ Recepción/Received: 2-X-09 \\ Aceptación/Accepted: 15-VI-10 \\ Publicado online/Online publishing: $14-\mathrm{X}-10$
}

\section{RESUMEN}

El presente estudio evalúa las posibilidades de utilización de lodos residuo de la industria del corte y tratamiento superficial del mármol para la producción de hormigón autocompactante (HAC). Se estudia el efecto del remplazo de un $30 \%$ del cemento por el residuo. Se valoran las características reológicas a nivel pasta y hormigón. La caracterización físico-mecánica contempla la evolución de la retracción y de la resistencia a compresión. Se comparan las prestaciones de pastas y hormigones empleando el residuo con mezclas que incorporan filler calizo, ya sea adicionado al hormigón o presente en el cemento. Se observa una mejora de la fluidez en el caso de los HAC que contienen el residuo estudiado; las propiedades mecánicas de éstos resultan equivalentes a las de los HAC con filler calizo. Se concluye que los lodos residuo del procesamiento del mármol pueden representan un filler adecuado para su uso en HAC.

Palabras claves: hormigón autocompactante, filler, residuo de mármol.

\section{SUMMARY}

This study evaluates the possibilities of using residual slurry from the cutting and superficial treatment of marble for the production of self-compacting concrete (SCC). The study considers the replacement of $30 \%$ of cement by the waste material, and assessed the effects on SCC properties in fresh and hardened states. Rheological characteristics were evaluated at the paste and concrete levels. Physical-mechanical characterization considers the rate of shrinkage and compressive strength gain. Pastes and concrete properties using waste marble as filler are compared with mixtures that include limestone filler, either added to the concrete or the cement. For the same dosage, an improvement in the flowability was observed in SCC with waste marble filler. The mechanical properties of the SCC adopting marble waste are equivalent to the SCC with limestone filler. The study shows that residual slurry from the processing of marble can represents an appropriate filler to be used in SCC.

Keywords: self-compacting concrete, filler, marble waste.

\footnotetext{
(*) Centro de Innovación, Investigación y Desarrollo en Ingeniería y Tecnología-UANL (Monterrey, México).

(**) BASF Construction Chemicals, Admixture Systems Europe (Treviso, Italia).

(***) AIDICO-Instituto Tecnológico de la Construcción (Valencia, España).

(****) Universidad de Sheffield (Sheffield, Reino Unido).
} 


\section{INTRODUCCIÓN}

En años recientes, los avances en la tecnología del hormigón se han enfocado en gran medida a desarrollar hormigones que apoyen la sostenibilidad medioambiental. Para lograrlo, una vía ha profundizado en las posibilidades de utilización de una gran gama de subproductos y residuos industriales que pueden contaminar el aire, agua o suelo, tales como la cenizas volantes, el humo de sílice, las escorias de horno alto, arenas de fundición, cenizas de cáscara de arroz, entre muchos otros (1-3). Como es de esperar, más allá de ser depositados o encapsulados en el hormigón, el uso de estos materiales modifica las propiedades del hormigón en estado fresco y endurecido y, en muchos casos, estos subproductos y residuos redundan en una mejora de las prestaciones reológicas, mecánicas y/o durables.

En este estudio, se ahonda en las posibilidades de utilización del residuo de la industria del corte y tratamiento superficial del mármol como filler para la producción de hormigón autocompactante.

Debido a las elevadas demandas mundiales del mármol, las cantidades de residuo generados por su industria está produciendo un impacto económico y ecológico difícilmente sostenible, ya que dichos residuos deben ser tratados, transportados y depositados en vertederos, con importantes costes de vertido.

En España, se estima que los vertidos ascienden a 700.000 toneladas anuales (4). Como ejemplo, en el sistema de corte de bloques de roca de mármol para la producción de placas de $20 \mathrm{~mm}$ de espesor, se produce un residuo en proporción de un 20-25\% respecto a la masa del bloque (5). En este caso, se estima un promedio de $170 \mathrm{~kg}$ de residuo seco por cada $\mathrm{m}^{3}$ de mármol tratado (6). La situación se presenta igual o más alarmante en otros países (7-9).

Con el objetivo inicial de mejorar la durabilidad de las estructuras, aspecto claramente vinculado a la sostenibilidad, nace en Japón el hormigón autocompactante (HAC) a finales de la década de los $80(10,11)$. La Instrucción de Hormigón Estructural Española, EHE, en su edición 2008, define dicho material como aquel hormigón que se compacta por la acción de su propio peso, sin necesidad de energía de vibración, ni de cualquier otro método de compactación, no presentando segregación, bloqueo del árido grueso, ni exudación. El documento de la Asociación Científico-Técnica del Hormigón Estructural, ACHE (12), complementa las especificaciones de la EHE y, de manera detallada, brinda las directrices a seguir para la dosificación, fabricación, caracterización y utilización del material. Dadas las prestaciones que se derivan de su definición, resulta evidente que el HAC representa el mayor desarrollo de la tecnología del hormigón en las últimas décadas.

\section{INTRODUCTION}

In recent years, most advances in concrete technology have been centered around the development of concretes that support environmental sustainability. For this purpose, one method has investigated the possibility of using an extensive range of industrial by-products and waste that may pollute air, water or soil, such as fly ash, silica fume, blast furnace slag, foundry sand, rice husk ash, among others (1-3). As expected, besides being deposited or encapsulated in concrete, the use of these materials modify the proprieties of concrete in a fresh and hardened state and, in many cases, these wastes or by-products will improve rheological and mechanical as well as durability properties.

This study investigates the possibilities of using waste from the cutting and superficial treatment of marble industry as filler for the production of self-compacting concrete.

Due to the global demand for marble, the amount of waste generated by this industry represents an economic and ecological impact that is becoming difficult to sustain since this waste must be handled, treated, transported and deposited in dump sites, with high dump costs.

In Spain, more than 700000 tons per year are dumped (4). For example, the marble block cutting system for the production of $20 \mathrm{~mm}$ thick plates produces waste at a ratio of $20-25 \%$ with respect to the block mass (5). In this case, an average of $170 \mathrm{~kg}$ of dry waste per $\mathrm{m}^{3}$ of treated marble is estimated (6). The situation is the same or even more alarming in other countries (7-9).

Self-compacting concrete (SCC) originated in Japan towards the end of the 1980's with the intention of improving the durability of structures, an aspect clearly related to sustainability $(10,11)$. The 2008 Spanish Structural Concrete Instruction, EHE, defines such material as the concrete compacted by its own weight, without the need of vibrating energy, nor any other compacting method, showing no segregation, thick aggregate blocking, or bleeding. The document of the Structural Concrete Scientific-Technical Association, ACHE (12), complements EHE specifications and it provides a detailed guideline for the dosage, manufacturing, characterization and use of the material. Based on its definition, it is evident that SCC represents the greatest development in concrete technology in recent decades. 
Para alcanzar la fluidez y cohesión características del $\mathrm{HAC}$ en estado fresco, habitualmente se recurre al aumento del volumen de pasta de la mezcla, lo cual influye de manera directa en la lubricación del sistema, que da lugar a la capacidad de fluir. Esta actuación conlleva a mayores contenidos de cemento y/o al empleo de finos minerales denominados fillers, por su función de relleno, con tamaños de partícula menores a $125 \mu \mathrm{m}$; por ejemplo, uno de los más habituales es el filler calizo obtenido del machaqueo de áridos. Es en este escenario donde se pretende influir con el uso del residuo de la industria del corte y tratamiento superficial del mármol; estudiando las posibilidades técnicas para su empleo como filler en HAC. En esencia, el polvo de mármol contenido en el residuo está formado principalmente por carbonato cálcico, totalmente comparable químicamente al filler calizo de machaqueo producido en Barcelona.

Es considerable la cantidad de trabajos donde se comprueba la idoneidad de finos calcáreos para la elaboración de hormigón (13-16). Corinaldesi et al. (17) indican que el polvo de mármol es una adición efectiva para mejorar la cohesión de las mezclas y que permite sustituir hasta un $10 \%$ de arena sin afectar la resistencia a compresión. En la misma línea, los resultados obtenidos por Benici et al. (18) demuestran una mayor resistencia a compresión de los hormigones con polvo residuo de mármol que en el caso de hormigones elaborados con igual contenido de filler calizo, y una notoria menor permeabilidad al agua en los primeros.

Zhu y Gibbs (19) estudian el uso de distintos tipos de fíllers de naturaleza caliza y de creta en HAC, concluyen que ambos son aptos para su uso como fíllers en HAC, con ligeras modificaciones en la dosificación de los aditivos, siendo ésta menor en el caso de los fíllers de naturaleza caliza. Los autores apuntan a que un incremento en el contenido de fíller permite reducir la dosificación de aditivos, permitiendo la obtención de HAC más económicos. Las resistencias mecánicas que obtienen son superiores a hormigones convencionales vibrados de referencia para la misma relación agua/cemento.

De esta manera, el HAC representaría una excelente opción para que estos finos dejen de ser un residuo y pasen a ser un componente necesario de este tipo de hormigones. Sin embargo, los estudios específicos relacionados con la utilización de este residuo de la industria del mármol para la elaboración de HAC son menos numerosos. Estudios llevados a cabo por Correia Gomes et al. (20) concluyen que la utilización de los residuos de corte de mármol y granito hasta en un $50 \%$ en peso del cemento, no conlleva ningún perjuicio para las propiedades de los hormigones y corroboran que la adición de dichos residuos ayuda a conseguir las propiedades de autocompactabilidad. Calmon et al. (7) reportan que los
An increase in the mixture paste volume is commonly used to obtain the fluidity and cohesion that characterizes SCC in a fresh state. This has a direct influence on the lubrication of the system resulting in relatively high flow capacity. Increased paste volume will demand greater cement content and/or the use of fine minerals known as fillers due to their filling function, with a particle size smaller than $125 \mu m$; for example, limestone is currently one of the most common fillers, obtained by the crushing or pulverizing process for aggregates. This investigation assesses the possibility of using waste from the marble industry, produced in the cutting and superficial treatment processes, as filler in SCC. Essentially, marble dust in the waste is formed mainly by calcium carbonate, which is chemically comparable to the crushed limestone filler produced in Barcelona.

There are many papers that confirm the suitability of fine calcareous materials for use as filler in concrete (13-16). Corinaldesi et al. (17) indicate that marble dust is an effective addition to improve the cohesion of mixtures and allows the substitution of up to $10 \%$ of sand without affecting compressive strength. Along the same lines, the results obtained by Benici et al. (18) show greater compressive strength of concrete with marble waste dust than in case of concrete using an equivalent limestone filler, and a notorious lower water permeability in the former.

Zhu and Gibbs (19) study the use of different types of limestone and creta fillers in SCC. They have come to the conclusion that both fillers are appropriate to be used in $S C C$, with minimum modifications in the admixture dosage and with a lower dosage in the case of limestone fillers. The authors point out that an increase in the filler content allows a reduction of the admixtures dosage, which leads to a more economic SCC. The mechanical strength obtained is higher than in the case of conventional vibrated concrete used as reference for the same water/cement ratio.

In this way, SCC would be an excellent way of utilising this material, and in fact is a beneficial element in this type of concrete. However, there are few specific studies related to the use of this waste product of the marble industry for use in SCC. Studies carried out by Correia Gomes et al. (20) conclude that using marble and granite waste up to $50 \%$ by cement weight will not adversely affect concrete properties and corroborate also that adding such waste helps achieve selfcompacting properties. Calmon et al. (7) report that marble and granite waste work as excellent filler for high strength SCC which allows a complete replacement of the limestone filler. Along the same line 
residuos de corte de mármol y granito representan un excelente filler para el HAC de alta resistencia, permitiendo reemplazar totalmente al filler calizo. En la misma línea, Topçu et al. (21) encuentran que la adición de hasta $200 \mathrm{~kg} / \mathrm{m}^{3}$ de residuo en HAC con cenizas volantes, mejora las propiedades en estado fresco y endurecido. Los estudios llevados a cabo por Nehdi et al. (22), permiten asimismo predecir una elevada durabilidad para HAC elaborados con este tipo de microfillers. En términos prácticos, Gupta et al. (23) encuentran que es difícil trabajar con el residuo en condición seca y que podría ser más factible su uso en forma de lechada.

Debido a la semejanza química que existe entre el polvo del residuo del corte de mármol y el filler calizo habitualmente utilizado en el HAC, Girbes et al. (24) han evaluado las posibilidades de sustituir el primero por el segundo. En este sentido, ensayos microestructurales han comprobado que la adición de filler o lodos del corte de mármol favorece la hidratación del cemento a tiempos cortos. En general, el uso del residuo como alternativa al tradicional filler calizo no altera la hidratación final de las pastas compuestas de cemento portland. Los HAC desarrollados presentaron una reología adecuada y resistencias que superaron las resistencias del HAC de referencia, es decir, sin residuo. Alyamaç e Ince (8) enfatizan que este residuo puede ser económicamente utilizado para la producción de HAC.

El presente trabajo evaluó el efecto de los lodos de corte de mármol sobre la fluidez y cohesión de pastas cementíceas, comparando su comportamiento con el de pastas equivalentes elaboradas con filler calizo, pastas de cemento tipo I y pastas de cemento tipo II (con adición de caliza), a través de los ensayos de cono de Marsh y mini-slump. Posteriormente, se optimizaron mezclas de HAC con dichas pastas, sobre las cuales se evaluaron las propiedades de autocompactabilidad a través de los ensayos normalizados de escurrimiento, escurrimiento con anillo J y embudo en $\mathrm{V}$, y la evolución en el tiempo de la retracción total y resistencia a compresión.

\section{MATERIALES}

Se utilizaron cementos CEM I 52,5 R y CEM II/B-L 32,5 $\mathrm{N}$, ambos con una superficie específica Blaine de $4.600 \mathrm{~cm}^{2} / \mathrm{g}$, según la ficha técnica provista por el fabricante. También, se utilizaron gravas y arenas calizas de machaqueo, de fracciones granulométricas 0-5 y 5-12 $\mathrm{mm}$, típicas de la región de Barcelona. El filler calizo utilizado como referencia es derivado del machaqueo de áridos calizos (situación habitual en la zona de Barcelona). Se utilizó un aditivo superplastificante (SP) basado en éteres policarboxílicos. of thought, Topçu et al. (21) find that adding up to 200 $\mathrm{kg} / \mathrm{m}^{3}$ of waste to fly ash SCC improves fresh and hardened properties. Studies carried out by Nehdi et al. (22) also predict a high durability of SCC made with this type of micro filler. In short, Gupta et al. (23) find that dry waste is difficult to manage and that it would be easier to use as slurry.

Due to the chemical similarity between marble waste powder and limestone filler commonly used in SCC, Girbes et al. (24) have evaluated the possibilities of substituting the limestone filler by marble. Micro structural tests have proved that adding filler or marble slurry allows cement hydration over a shorter period of time. In general, the use of marble waste as an alternative to the limestone filler does not alter the final hydration of the Portland cement paste. The resulting SCC exhibits a proper rheology and mechanical strength that exceeded those of the reference SCC without marble waste. Alyamaç and Ince (8) emphasize that this waste could be economically used for the production of SCC.

In this paper, the Marsh cone and the mini-slump tests were used to evaluate the effect of slurry from marble cuttings on the fluidity and cohesion of cementitious pastes, comparing their behavior with those of similar pastes made with limestone filler, type I cement and type II cement pastes (with limestone). Subsequently, SCC mixtures were optimized with those pastes. The self-compacting properties of those mixtures were examined through the standard slump-flow, with J-ring and $V$-funnel tests. The evolution of the total shrinkage and compressive strength were also evaluated.

\section{MATERIALS}

CEM I 52.5 R and CEM II/B-L 32.5 N cements were used. Both cements had a Blaine specific surface of 4600 $\mathrm{cm}^{2} / \mathrm{g}$ according to the technical sheet provided by the manufacturer. Also, crushed coarse and sand aggregates with 0-5 and 5-12 mm granulometric fractions, typical of the Barcelona region, were used. The limestone filler used as reference was obtained from crushed limestone aggregates that are common in the Barcelona area. $A$ polycarboxylate ether based superplasticizer (SP) was also used. 
El residuo de la industria del mármol considerado, se genera inicialmente en forma de lodo, producto del tratamiento de prensado al que son sometidos dichos lodos previo a su almacenaje (con el objetivo de que ocupen menos volumen). Posteriormente, se presentan en forma de terrones de una masa húmeda y poco manejable, floculados a partir de aditivos químicos y prensados, con poca uniformidad en cuanto a su contenido de humedad. Este hecho motivó su utilización en forma de lechada, la cual fue realizada simplemente añadiendo agua y mezclando enérgicamente, hasta disolver totalmente los terrones y grumos, y alcanzar una lechada fluida y homogénea, Figura 1.
The marble industry waste under consideration is initially generated as slurry resulting from the pressing method performed on this material before storage (in order to reduce the space required). This slurry is in the form of wet mass lumps that are flocculated with chemical admixtures or additives and then pressed, with little uniformity in their humidity content, hence is difficult to manage. This motivated its use as slurry, made consistent by adding water and mixing energetically until all the lumps were dissolved to reach a fluid and homogeneous slurry, Figure 1.

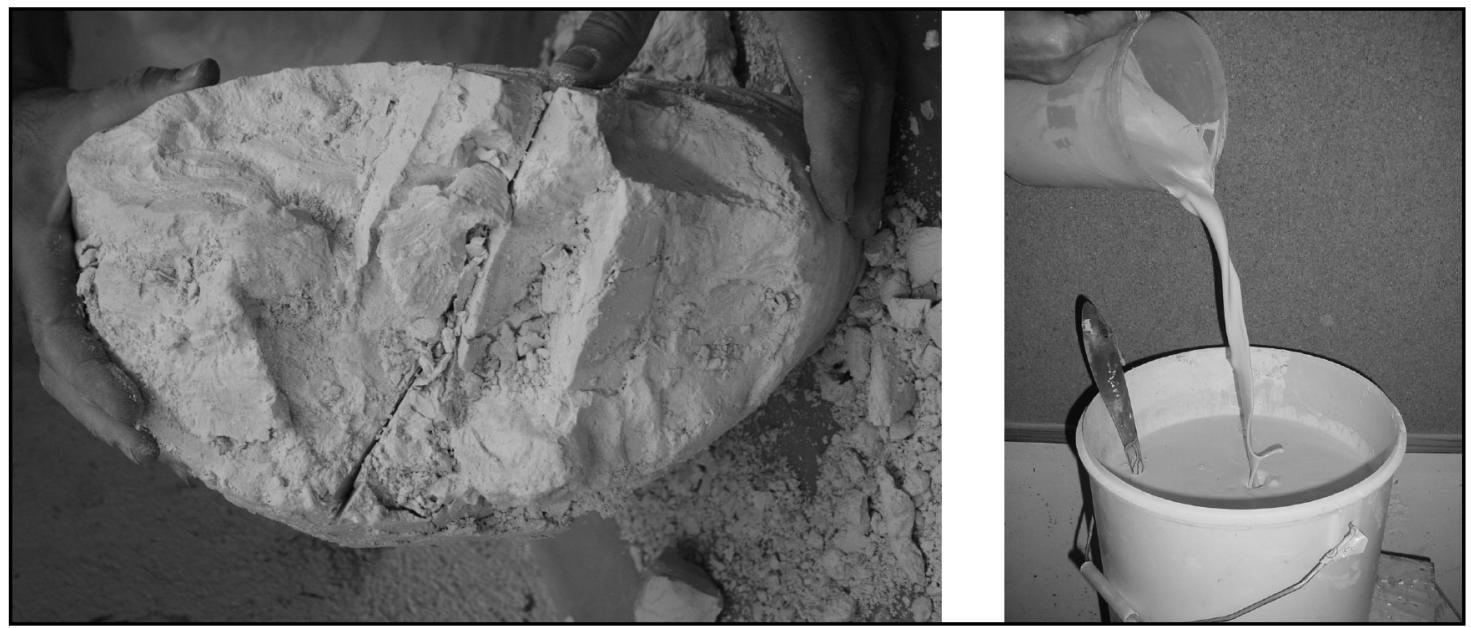

Figura 1. Aspecto del residuo en su estado original (izquierda) y de la lechada fabricada con el mismo (derecha). Figure 1. Aspect of marble waste lumps (left) and slurry produced with it (right).

Los resultados del análisis de distribución de partículas de los fillers estudiados, filler calizo (FC) y polvo de mármol (PM), se presentan en la Figura 2. Como se puede observar, las partículas del polvo de mármol son más finas que las del filler calizo; con un promedio de tamaño de partícula de $4 \mu \mathrm{m}$ y $8 \mu \mathrm{m}$, respectivamente. La Tabla 1 presenta la composición química de los dos tipos de finos minerales.
The results of the particle size distribution analysis of the fillers under study, limestone filler (LF) and marble powder (MP) are shown in Figure 2. As it can be observed, marble powder particles are finer than those of limestone filler, with an average particle size of $4 \mu \mathrm{m}$ and $8 \mu \mathrm{m}$, respectively. Table 1 shows the chemical composition of the two fine minerals.

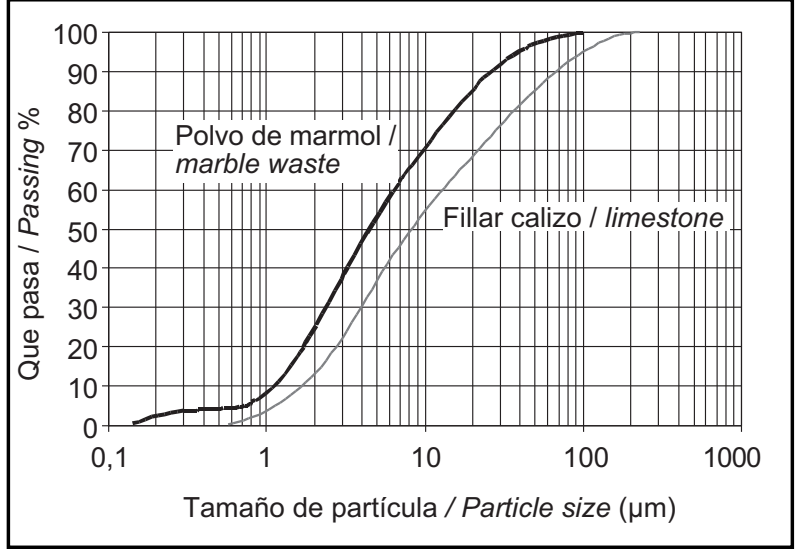

Figura 2. Distribución granulométrica del filler calizo y lodos del corte de mármol.

Figure 2. Particle size distribution of limestone filler and marble waste powder. 
Tabla 1 / Table 1

Composición química del polvo de mármol y filler calizo de referencia (\% en peso).

Chemical composition of marble powder and reference limestone filler (\% in weight).

\begin{tabular}{|c|c|c|c|c|c|c|c|c|c|}
\hline $\begin{array}{c}\text { Fino mineral / } \\
\text { Fine materials }\end{array}$ & $\mathrm{SiO}_{2}$ & $\mathrm{Al}_{2} \mathrm{O}_{3}$ & $\mathrm{Fe}_{2} \mathrm{O}_{3}$ & $\mathrm{CaO}$ & $\mathbf{M g O}$ & $\mathbf{S O}_{3}$ & $\mathrm{~K}_{2} \mathrm{O}$ & $\mathrm{Na}_{2} \mathrm{O}$ & P.F.1 \\
\hline $\begin{array}{c}\text { Residuo de mármol / } \\
\text { Marble waste powder }\end{array}$ & 0.36 & 0.00 & 0.04 & 55.32 & 0.44 & 0.1 & 0.001 & 0.02 & 43.35 \\
\hline Filler calizo / Limestone filler & 7.81 & 1.25 & 0.80 & 48.39 & 1.61 & 0.04 & 0.3 & 0.16 & 39.64 \\
\hline
\end{tabular}

1 Pérdida al fuego / Loss on ignition.

Se consideró una relación agua/cemento efectiva, a/c= 0,45 , la cual considera el agua aportada por la lechada de lodos y del SP.

\section{PROGRAMA EXPERIMENTAL}

Se evaluó la posibilidad de uso del residuo en la producción de HAC mediante estudios sobre la fase pasta (agua+ cemento+ filler o lodos+ SP). De esta manera, a través de dos ensayos sencillos como el del cono de Marsh (25) y el minicono de Kantro (26), puede evaluarse cualquier incompatibilidad entre los componentes, obtener la dosis de saturación del SP y las proporciones que conlleven a una fluidez y cohesión adecuadas para la elaboración de HAC.

Cabe mencionar que la posibilidad de incompatibilidad entre componentes es de especial importancia, puesto que, como se menciona en el apartado anterior, los lodos producto del corte de mármol contienen en su masa aditivos floculantes, que permiten su mejor manipulación y almacenamiento inicial. Evidentemente, dichos aditivos tienen una acción opuesta a la de los SP empleados en HAC, que son esencialmente desfloculantes de partículas de cemento.

La optimización de la fase pasta es el primer paso del método de diseño de mezclas desarrollado por investigadores de la UPC $(27,28)$, en el que se basó el diseño de las mezclas de HAC consideradas en este estudio. El segundo paso corresponde a la obtención del esqueleto granular que conlleve a la máxima compacidad para los áridos considerados, para lograr lo anterior, se siguen las especificaciones de la Norma ASTM C29/C29M (29), pero eliminando la compactación. Finalmente, se realizan HAC con contenidos crecientes de pasta, por encima del índice de vacíos obtenido en el segundo paso, hasta alcanzar las condiciones de autocompactabilidad requeridas.

Para los ensayos sobre pastas se consideraron las siguientes combinaciones de finos:

P-CEM I (P1): $100 \%$ CEM I 52,5 R

P-FC (P2): 70\% CEM I 52,5 R + 30\% filler calizo

P-PM (P3): 70\% CEM I 52,5 R + 30\% polvo de mármol

P-CEM II (P4): $100 \%$ CEM II/ B-L 32,5 N
An effective water/cement ratio of 0.45 was considered, which includes the water provided by the slurry and the $S P$.

\section{EXPERIMENTAL PROGRAM}

The study evaluated the use of waste in the production of SCC by studying the paste phase (water + cement + filler or slurry $+S P)$. Any incompatibility among components could be evaluated through two simple tests such as the Marsh cone (25) and the Kantro mini-slump cone (26) tests to obtain the saturation dosage of the SP and the proportions that lead to the appropriate fluidity and cohesion for the production of SCC.

It is worth mentioning how important it is to consider the possibility that the components are not compatible. As previously mentioned the slurry resulting from marble cutting contains flocculating additives which allow a better handling and initial storage. Evidently, these additives have an opposite effect to those employed in SCC, which are essentially deflocculants of cement particles.

Optimizing the paste phase is the first step of the mixture design method developed by UPC researchers $(27,28)$. This was the basic method for the SCC mixtures considered in this study. The second step consists in obtaining the granular skeleton that leads to the maximum compactibility for the considered aggregates. To achieve this, The ASTM C29/C29M Standard specification (29) was followed and the compaction process was eliminated. Finally, SCC with higher paste contents above the void ratio obtained in the second step until the required self-compactibility conditions were met.

The following fines mixtures were considered for the paste tests:

P-CEM I (P1): $100 \%$ CEM I $52.5 R$

$P$-LF (P2): 70\% CEM I $52.5 R+30 \%$ limestone filler

$P-M P(P 3): 70 \%$ CEM I $52.5 R+30 \%$ marble powder P-CEM II (P4): $100 \%$ CEM II / B-L $32.5 \mathrm{~N}$ 
Como cemento compuesto, el CEM II/ B-L 32,5 N puede contener entre un $21 \%$ y un $35 \%$ de caliza $y$, según el fabricante del cemento utilizado, dicho valor se encuentra habitualmente en un $30 \%$. Por tanto, resultan comparables las combinaciones P-FC, P-PM, y P-CEM II anteriores, representando posibilidades que se pueden dar en la práctica.

Las pastas fueron amasadas en una mezcladora tipo Hobart, con la siguiente secuencia: primero los materiales secos fueron homogeneizados durante 1 minuto a 28 r.p.m. Después de dicho tiempo se incorporó el agua y seguidamente la lechada de lodos, de ser el caso. Se continuó el mezclado a 28 r.p.m. durante 1 minuto más. Se detuvo la amasadora y se incorporó el SP. Posteriormente se mezcló durante 1 minuto a 28 r.p.m y pasado este tiempo se detuvo la amasadora para raspar los lados de la cuba con una paleta y asegurar que no hubiese material adherido a las paredes y el fondo. Finalmente, se agitó la mezcla a 52 r.p.m durante 1 minuto. Seguidamente se realizan los ensayos.

Además de estudiar las características reológicas a nivel pasta a través de los ensayos mencionados, se evaluó también la influencia del tiempo sobre dichas medidas, hasta los 120 minutos. De esta manera se pueden detectar comportamientos inadecuados en lo que se refiere al tiempo abierto del HAC, o tiempo a lo largo del cual se mantienen sus características de autocompactabilidad.

Los ensayos experimentales para la obtención del esqueleto granular arrojaron la máxima compacidad para una relación arena/grava $=60 / 40$. Con dicha relación, se alcanzó un valor adecuado de autocompactabilidad con un contenido de pasta del $39 \%$ en volumen (390 litros $/ \mathrm{m}^{3}$ ).

Las pastas P-FC, P-PM, y P-CEM II estudiadas fueron utilizadas para la elaboración de sendos hormigones autocompactantes. Las amasadas se realizaron en una mezcladoras de 65 litros; primeramente se vertieron los materiales secos y se mezclaron durante 30 segundos para homogenizarlos, posteriormente se adicionó el agua y en su caso el lodo de mármol, seguido de una agitación de 2 minutos, por último se añadió el aditivo y se mezclaron todos los componentes durante un período final de 5 minutos.

A nivel hormigón, en estado fresco se midieron los principales parámetros de autocompactabilidad; el escurrimiento (30), para el cual se midió en diámetro final $\left(D_{f}\right)$ y el tiempo para alcanzar una extensión de $500 \mathrm{~mm}$ $\left(T_{50}\right)$, el tiempo de vaciado en el embudo en $\mathrm{V}\left(\mathrm{T}_{\mathrm{V}}\right)(31)$ y el escurrimiento con anillo japonés (32), midiendo el diámetro final $\left(D_{\mathrm{fJ}}\right)$ y el tiempo en alcanzar un diámetro de $500 \mathrm{~mm}\left(\mathrm{~T}_{50 \mathrm{~J}}\right)$. Adicionalmente, se determinó el peso unitario (PU) del hormigón fresco.
As a blended cement, CEM II/B-L $32.5 \mathrm{~N}$ may contain between $21 \%$ and $35 \%$ percent of limestone. According to the cement manufacturer, this value is usually $30 \%$. Therefore, previous $P-L F, P-M P$ and P-CEM II combinations are comparable, which represent possibilities that could be transferred to practice.

Pastes were prepared using a Hobart mixer with the following sequence: first, dry materials were homogenized for 1 minute at $28 \mathrm{rpm}$. Afterwards, water and slurry, if applicable, were added. Mixing continued for 1 more minute at $28 \mathrm{rpm}$. The mixer stopped and the SP was incorporated. Subsequently, it was mixed for 1 additional minute at $28 \mathrm{rpm}$. Then, the mixer was stopped to scrape the sides of the container with a spatula and make sure that there were no materials adhered to the sides and the bottom. Finally, the mixture was agitated at $52 \mathrm{rpm}$ for 1 minute. Next, the tests were carried out.

Besides studying the rheological characteristics of the paste through the tests mentioned above, the influence of time was also evaluated upon such measures up to minute 120. In this way inappropriate behavior can be detected regarding the SCC open time, or the time during which its self-compactibility characteristics are maintained.

Experimental trials to obtain the granular skeleton showed the maximum compactibility for the sand/gravel ratio $=60 / 40$. The appropriate value of self-compactibility was reached with this ratio, with a volume paste content of $39 \%$ (390 liters $\left./ \mathrm{m}^{3}\right)$.

The pastes studied ( $P$-LF, P-MP and P-CEM II) were used as filler in the corresponding self-compacting concretes. Batches were mixed in a 65 liter mixer; first, dry materials were poured and mixed for 30 seconds to blend them, water and in this case the marble slurry were then added and stirred for 2 minutes. Finally, the chemical admixture was added and mixed with the rest of the ingredients for a final period of 5 minutes.

At a fresh state concrete level, the self-compacting main parameters where measured; the flow spread (30), for which the final diameter $\left(D_{f}\right)$ and the time to reach a length of $500 \mathrm{~mm}\left(T_{50}\right)$ was measured, pouring time in the $V$-funnel $\left(T_{v}\right)(31)$ and slump flow in the J-ring (32), measuring the final diameter $\left(D_{f J}\right)$ and the time to obtain a $500 \mathrm{~mm}$ diameter $\left(T_{50 \mathrm{~J}}\right)$. The unit weight (UW) of the fresh concrete was also determined. 
Con las mezclas obtenidas se moldearon probetas cilíndricas de 100 × 200 mm para la evaluación de la evolución de la retracción y de la resistencia a compresión hasta la edad de 28 días.

A las 24 horas de fabricadas, las probetas se desmoldaron y ubicaron en cámara húmeda $(98 \pm 2 \%$ de humedad relativa). Las probetas para retracción se curaron durante 7 días. Posteriormente, estas probetas fueron instrumentadas con puntos Demec (separados $150 \mathrm{~mm}$ y dispuestos sobre 2 líneas verticales opuestas) e introducidas en una cámara climática a $50 \%$ de humedad relativa y $20^{\circ} \mathrm{C}$. Las probetas para la evaluación de la resistencia a compresión permanecieron en cámara húmeda hasta la edad de ensayo.

\section{RESULTADOS Y DISCUSIÓN}

\subsection{Pastas}

En las Figuras 3 y 4 se presenta el comportamiento de las pastas estudiadas en relación al tiempo de flujo a través del cono Marsh y diámetro de escurrimiento en el ensayo de minicono respectivamente, para diferentes dosificaciones de aditivo.

De la Figura 3 se puede observar un comportamiento muy similar de las pastas elaboradas con un $100 \%$ de CEM I 52,5 R (P1), aquellas en las que se remplazó un $30 \%$ de dicho cemento por residuo del corte de mármol (P3), y las elaboradas con el $100 \%$ de CEM II/B-L 32,5 N (P4). Sin embargo, se evidencia un ligero aumento del tiempo de flujo (menor fluidez) en el caso de la pasta P2, que contiene un $70 \%$ de CEM I 52,5 R + 30\% de filler calizo.

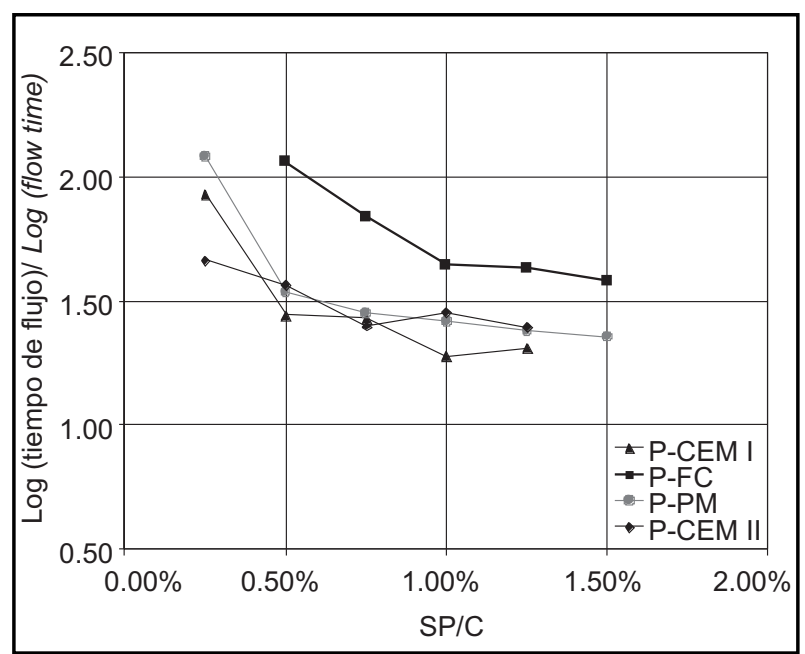

Figura 3. Cono de Marsh- Logaritmo del tiempo de flujo en función de la dosis de superplastificante (\% en peso del cemento). Figure 3. Marsh cone- Logarithm of flow time vs superplasticizer dosage (\% of cement weight).
With these mixtures, $100 \times 200 \mathrm{~mm}$ cylindrical test specimens were cast to evaluate shrinkage development and compressive strength up until 28 days old.

At 24 hours, the test specimens were demolded and placed in a curing room ( $98 \pm 2 \%$ relative humidity). The test specimens for shrinkage were cured for 7 days. Subsequently, the specimens were prepared with Demec points (separated at $150 \mathrm{~mm}$ and arranged in 2 opposite vertical lines) and introduced into a controlled climate chamber at $50 \%$ relative humidity and $20^{\circ} \mathrm{C}$. The test specimens for the evaluation of the compressive strength remained in the curing room until the test age was reached.

\section{RESULTS AND DISCUSSION}

\subsection{Pastes}

For different admixture dosages, Figures 3 and 4 shows the behavior of the studied pastes with regards to their flow time through the Marsh cone and the slump flow diameter in the mini-slump cone test respectively.

Figure 3 shows that the behavior of the pastes made with $100 \%$ of CEM I 52,5 R (P1) was similar to those where $30 \%$ of the cement was replaced by marble cutting waste (P3), and those made with $100 \%$ of CEM II/B-L 32.5 N (P4). A slight increase in the flow time (less fluidity) can be seen in the case of the $P 2$ paste, which contains $70 \%$ of CEM I $52.5 R+30 \%$ of limestone filler.

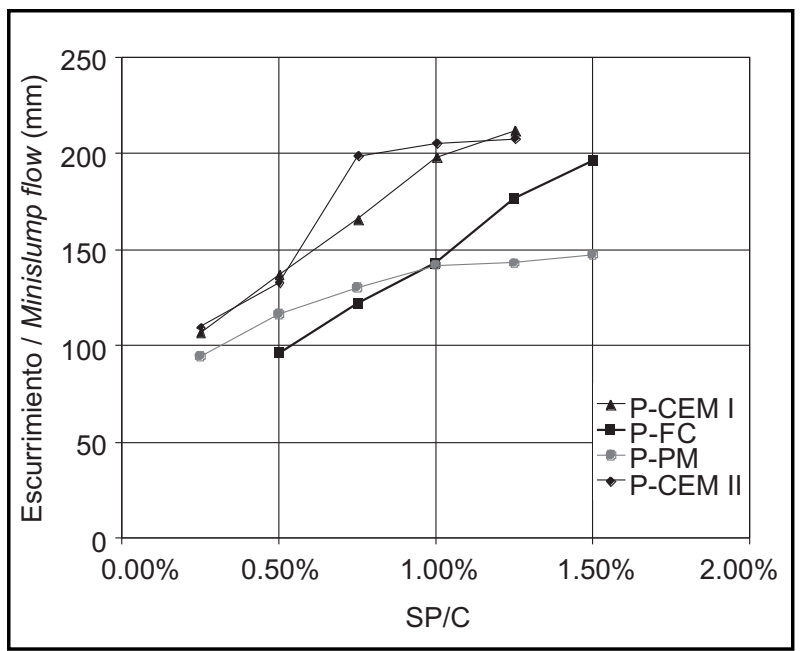

Figura 4. Minicono- Escurrimiento en función de la dosis de superplastificante (\% en peso del cemento).

Figure 4. Mini-slump flow- Spread vs superplasticizer dosage (\% of cement weight). 
Los resultados del minicono muestran los mayores diámetros de escurrimiento para el caso de las pastas P-CEM I y P-CEM II a lo largo de todo el intervalo analizado. La pasta P-FC presenta los menores diámetros de escurrimiento hasta una dosis de SP del $1 \%$. La pasta P-PM parece presentar un punto de saturación definido en el entorno del $1 \%$, a partir del cual un incremento en el contenido de SP no redunda en mayores diámetros de escurrimiento.

En términos de fluidez, el análisis de la Figura 3 permite estimar que el punto de saturación del SP está en el orden del 0,50\% para las pastas P-CEM I y P-PM, 0,75\% para la pasta P-CEM II, y en torno al $1,00 \%$ para la pasta P-FC. Sin embargo, según la metodología de dosificación seguida, la pasta debe a su vez alcanzar un diámetro mínimo de $170 \mathrm{~mm}$ en el ensayo de minicono, por lo que, según la Figura 4, la dosis de SP se incrementaría a $0,75 \%$ para la pasta P-CEM I, se mantendría en este mismo valor en el caso de la pasta P-CEM II, pero se debería incrementar al $1,25 \%$ en la pasta P-FC. La pasta P-PM no parece poder alcanzar el valor de escurrimiento recomendado para dosis de SP de hasta $1,50 \%$ (valor por encima del cual se observó segregación).

Asumiendo que el comportamiento reológico de la pasta de cemento puede asimilarse al modelo de Bingham (33) y relacionando el tiempo de pasaje por el cono de Marsh con la viscosidad plástica (34), y el diámetro de escurrimiento del minicono con la tensión umbral, se puede observar que las pastas P-CEM I, P-PM y P-CEM II presentan viscosidades plásticas similares para dosis de SP por encima de $0,5 \%$. Los mayores tiempos de flujo de la pasta P-FC estarían indicando que se está en presencia de una pasta más viscosa. Una mayor viscosidad podría dar lugar a mezclas más resistentes a la segregación, pero ésta debe venir acompañada de una baja tensión umbral, que permita alcanzar una mayor fluidez.

Un aspecto de importancia práctica mayor es la idoneidad de las mezclas en términos del "tiempo abierto" requerido por la aplicación, o tiempo durante el cual se mantienen las condiciones especificadas de autocompactabilidad. Este tiempo podría verse notablemente afectado en caso de que existiera alguna incompatibilidad entre los componentes utilizados. En este caso, como fue mencionado, este aspecto reviste especial interés, ya que los lodos de corte de mármol contienen aditivos floculantes que podrían afectar al tiempo abierto.

En la Figura 5 se puede observar la fluidez de las diferentes pastas con el transcurso del tiempo, como respuesta del ensayo del cono de Marsh. Las pastas P-CEM I y P-CEM II fueron elaboradas con un contenido de $\mathrm{SP}=0,75 \%$, y las pastas P-FC y $\mathrm{P}-\mathrm{PM}$ con $\mathrm{SP}=1 \%$. Del comportamiento observado no se evidencian importantes pérdidas de fluidez
The mini-slump cone results show higher slump flow diameters for P-CEM I and P-CEM II pastes throughout the analyzed interval. The P-LF paste shows smaller slump flow diameters up to an SP dose of $1 \%$. The P-MP paste seems to show a saturation point around $1 \%$, after which an increase in SP content does not increase the slump flow diameter.

In terms of fluidity, the analysis in Figure 3 shows that the saturation point of the SP is within the range of $0.50 \%$ for the P-CEM I and P-MP pastes; $0.75 \%$ for the P-CEM II paste and around $1.00 \%$ for the P-LF paste. However, depending on the selected dosage method, the paste must reach a minimum diameter of $170 \mathrm{~mm}$ in the minislump cone test. Thus, according to Figure 4, the SP dose should be increased up to $0.75 \%$ for the P-CEM I paste whilst a value of $0.75 \%$ should be maintained for the $P$ CEM II paste. The SP dose should be increased to $1.25 \%$ for the $P-L F$ paste to achieve the minimum diameter, however it seems that the P-MP paste cannot reach the slump flow value of up to $1.50 \%$ recommended for the SP dose (segregation was observed above this value).

Assuming that the rheological behavior of the cement paste may resemble the Bingham model (33) and by relating the flow rate through the Marsh cone with plastic viscosity (34), and the mini-slump cone flow diameter with the threshold tension, it can be observed that $P$ CEM I, P-MP and P-CEM II pastes show similar plastic viscosities for the $S P$ dosages above $0.5 \%$. High flow rates for the $P$-LF paste would indicate a more viscous paste. A higher viscosity would render mixtures highly resistant to segregation, but these must be accompanied by a low yield stress to allow a higher fluidity.

An important practical aspect is the suitability of the mixtures in terms of the "open time" required for the application or the period of time during which the specified self-compacting conditions are maintained. This period of time may be notably affected if the used ingredients turned out to be incompatible. In such case, as it has been mentioned, suitability is especially important since the marble slurry contains flocculating additives that may affect open time.

Figure 5 illustrates the fluidity of the different pastes by showing the time taken to complete the Marsh cone test after increased periods of "open time". P-CEM I and PCEM II pastes were elaborated with a content of $S P=0.75 \%$; and $P-L F$ and $P-M P$ were made with a $S P=1.00 \%$. During the first two hours after mixing, no 
durante las primeras dos horas posteriores a la fabricación. De hecho, las pastas conteniendo lodos de corte de mármol presentan la mayor fluidez (menor tiempo de pasaje) y las menores pérdidas de la misma con el tiempo. significant losses of fluidity were observed in the behavior. In fact, pastes with marble slurry showed the highest fluidity (less passage rate) and lowest losses of fluidity with time.

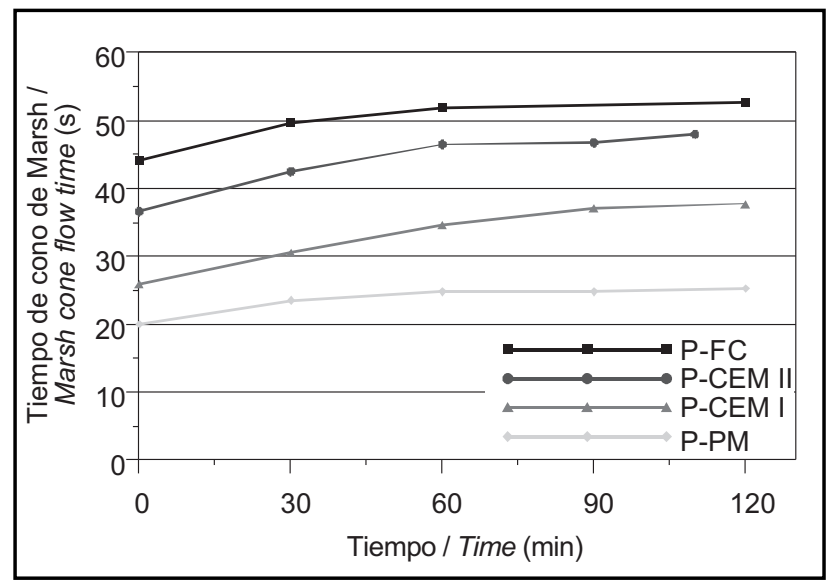

Figura 5. Evolución de la fluidez de las pastas con el transcurso del tiempo.

Figure 5. Paste fluidity evolution.

\subsection{Hormigones autocompactantes}

La composición de los tres HAC y las medidas de autocompactabilidad se muestran en la Tabla 2. Las denominaciones HAC-FC, HAC-PM y HAC-CEMII corresponden a hormigones elaborados con las pastas P-FC, P-PM y PCEM II, respectivamente. El contenido de SP se fijó en el $1,25 \%$ del peso del cemento para las tres mezclas; dosis para la que las pastas P-FC y P-CEM II alcanzaron un diámetro mayor a $170 \mathrm{~mm}$ en el ensayo de minicono (mínimo recomendado por Correia Gomes (27)). En el caso de la pasta P-PM, si bien el diámetro de escurrimiento a nivel pasta no alcanzó dicho valor, tampoco ocurría para mayores contenidos de SP.

Como se puede observar de la Tabla 2, los HAC estudiados presentan diámetros de escurrimiento, $D_{f}$, entre 625 y $705 \mathrm{~mm}$. De esta manera, si se considera la clasificación propuesta por la Instrucción de Hormigón Estructural Española (EHE, 2008), para el nivel de autocompactabilidad en función del diámetro de escurrimiento, el HAC-FC correspondería a la clase $1\left(550 \leq \mathrm{D}_{\mathrm{f}}<650\right.$ $\mathrm{mm})$, mientras los casos HAC -PM y HAC-CEMII corresponderían a la clase $2\left(650 \leq \mathrm{D}_{\mathrm{f}}<750 \mathrm{~mm}\right)$, dicha clasificación se presenta en la Figura 6.

Los tiempos de pasaje a través del embudo en $V, T_{V}$, se encuentran entre 4 y 8 segundos, con el HAC-PM presentando el menor $\mathrm{T}_{\mathrm{V}}$. La resistencia al bloqueo fue evaluada a través de la diferencia entre el diámetro de escurrimiento y el de escurrimiento con anillo $\mathrm{J}, \Delta \mathrm{J}=\mathrm{D}_{\mathrm{f}}-\mathrm{D}_{\mathrm{f}}$; en general, se recomienda que el valor de $\Delta \mathrm{J}$ no supere los 50 $\mathrm{mm}$. Como se puede observar de la Tabla 2, el HAC-FC

\subsection{Self-compacting concrete}

Table 2 shows the composition of the three SCC and the self-compacting measured parameters. SCC-LF, SCC-MP and SCC-CEMII denominations correspond to concrete elaborated with P-LF, P-MP and P-CEM II pastes, respectively. The SP content was fixed at $1.25 \%$ of the cement weight for the three mixtures. P-LF and P-CEM II pastes achieved a diameter higher than $170 \mathrm{~mm}$ in the mini-slump cone test with that dosage (minimum recommended by Correia Gomes (27)). For the P-MP paste, the minimum recommended diameter of slump was not achieved even for higher contents of SP.

As shown in Table 2, SCC under study show slump flow diameters, $D_{f}$, between 625 and $705 \mathrm{~mm}$. In this way, if the classification proposed by the Spanish Structural Concrete Instruction (EHE, 2008) is adopted for the selfcompactibility level in relation to the slump flow diameter, the SCC-LF would correspond to a class 1 (550 $\leq D_{f}<$ $650 \mathrm{~mm})$, while SCC-MP and SCC-CEM II would correspond to a class $2\left(650 \leqq D_{f}<750 \mathrm{~mm}\right)$. This classification is shown in Figure 6.

The times of passage through the $V$-funnel, $T_{V}$, are between 4 and 8 seconds, with SCC-MP showing the lower $T_{v}$. Blocking resistance was evaluated through the difference between the slump flow diameter and the slump flow with J-ring $\Delta \mathrm{J}=D_{f}-D_{f j}$; in general, is recommend that the value of $\Delta \mathrm{J}$ does not exceed $50 \mathrm{~mm}$. According to Table 2, SCC-LF shows a value of $\Delta \mathrm{J}$ slightly 
Tabla 2 / Table 2

Composición de los HAC y medidas de autocompactabilidad. SCC composition and Self-Compactability properties.

\begin{tabular}{|c|c|c|c|}
\hline Componente / Component $\left(\mathrm{kg} / \mathrm{m}^{3}\right)$ & HAC-FC & HAC-PM & HAC-CEMII \\
\hline CEM I $52.5 \mathrm{R}$ & 398 & 398 & \\
\hline CEM II/B-L $32.5 \mathrm{~N}$ & & & 518 \\
\hline Agua / Water & 179 & 179 & 179 \\
\hline Filler caliza / Limestone filler & 119 & & \\
\hline Residuo mármol / Marble waste powder & & 119 & \\
\hline Arena / Sand 0-5 & 963 & 963 & 963 \\
\hline Grava / Coarse aggregate 5-12 & 647 & 647 & 647 \\
\hline Superplastificante / superplasticizer & 5 & 5 & 5 \\
\hline \multicolumn{4}{|l|}{ Ensayos / Tests } \\
\hline$D_{f}$ & 625 & 690 & 705 \\
\hline$T_{50}$ & 1.2 & 1.1 & 1.8 \\
\hline $\mathrm{T}_{\mathrm{V}}$ & 6.5 & 4.4 & 8.3 \\
\hline$D_{f J}$ & 570 & 645 & 660 \\
\hline$T_{50 J}$ & ND & 1.7 & 3.3 \\
\hline$\Delta \mathrm{J}=\mathrm{D}_{\mathrm{f}}-\mathrm{D}_{\mathrm{fJ}}$ & 55 & 45 & 45 \\
\hline$C_{b J}$ & 0.91 & 0.94 & 0.92 \\
\hline
\end{tabular}

ND $=$ no disponible.

presenta un valor de $\Delta \mathrm{J}$ ligeramente superior al límite recomendado. Sin embargo, teniendo en cuenta la propia variabilidad del ensayo, que se parte de un menor valor de $\mathrm{D}_{\mathrm{f}}, \mathrm{y}$ el adecuado aspecto visual del material, puede considerarse que no se está en presencia de una mezcla con baja capacidad de paso entre las barras de armadura. Las mezclas HAC-PM y HAC-CEMII no evidenciaron ningún signo de bloqueo.

Comparando los hormigones HAC-FC y HAC-PM elaborados con filler y polvo de mármol, respectivamente, se observa una significativa ganancia de fluidez en el caso del HAC-PM (para la misma dosis de SP). En términos reológicos, si se considera a los parámetros $D_{f}$ y $T_{V}$ como medidas indirectas de los parámetros de tensión umbral y viscosidad respectivamente $(35,36)$, se puede observar que el HAC-PM presentaría menores valores de tensión umbral y viscosidad. En este sentido, los tres higher than the recommended limit. However, taking into consideration the variability of the essay which starts from a lower value of $D_{f}$, and the proper visual aspect of the material, it can be considered that it is not a mixture with low passage capacity among the reinforcing bars. SCC-MP and SCC-CEMII mixtures showed no indication of blocking.

Comparing SCC-LF and SCC-MP concrete made with filler and marble powder respectively, a significant gain of fluidity was observed in the case of SCC-MP (for the same SP dose). In rheological terms, if the $D_{f}$ and $T_{v}$ parameters are considered as indirect measurements of yield stress and viscosity parameters respectively (35, 36), it can observed that SCC-MP would show lower values for yield stress and viscosity. In this sense, the three SCC reach proper combinations in general

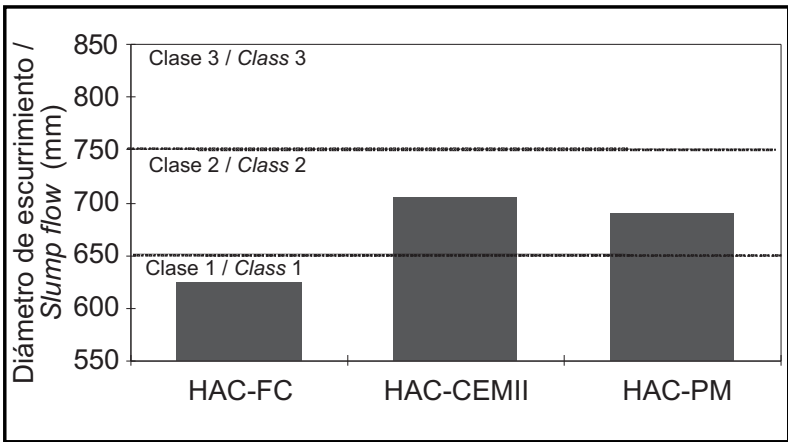

Figura 6. Escurrimientos obtenidos y correspondientes clases de autocompactabilidad según EHE 2008.

Figure 6. Slump flow for the different concretes and comparison with the SCC classes established in the EHE 2008 Spanish Structural Design Code. 
HAC alcanzan combinaciones adecuadas en términos generales; una baja tensión umbral (mayor fluidez) y una moderada viscosidad (que evite la segregación).

\subsection{Retracción}

La Figura 7 muestra la evolución de la retracción total de las probetas, las cuales fueron curadas por 7 días en cámara húmeda $\left(98 \pm 2 \% \mathrm{HR}, 20^{\circ} \mathrm{C}\right)$ y posteriormente mantenidas en cámara seca $\left(50 \% \mathrm{HR}, 20^{\circ} \mathrm{C}\right)$ hasta la edad de 28 días. Como se puede apreciar, no existen diferencias de comportamiento significativas, mostrando los tres HAC valores de deformación por retracción total en torno a las 450 microdeformaciones, a los 28 días de edad, con las tres mezclas evidenciando una evolución muy similar hasta dicha edad. terms; low yield stress (more fluidity) and moderate viscosity (preventing segregation).

\subsection{Shrinkage}

Figure 7 shows the total shrinkage evolution of the test specimens that were cured for 7 days in a fog room (98. $\left.2 \% \mathrm{RH}, 20^{\circ} \mathrm{C}\right)$ and afterwards in a dry chamber (50\% $R H, 20^{\circ} \mathrm{C}$ ) up to an age of 28 days. It can be seen that there are no significant differences in the behavior among the three SCC, showing total shrinkage deformation values around 450 microstrains at 28 days; the three mixtures show a very similar evolution for that period of time.

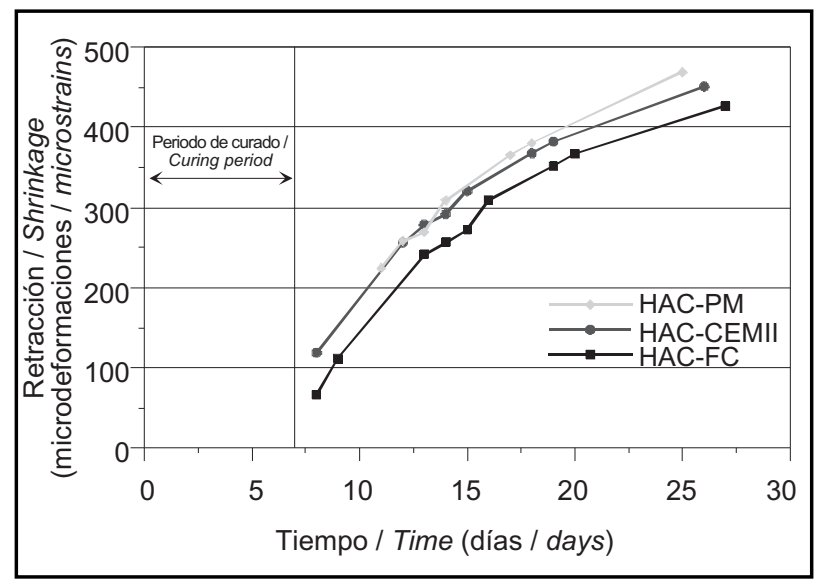

Figura 7. Evolución de la retracción con el tiempo. Figure 7. Shrinkage evolution along time.

\subsection{Resistencia a compresión}

La Tabla 3 presenta la evolución de la resistencia a compresión hasta los 28 días de edad, para los tres HAC. Como se puede observar, las respuestas de los tres hormigones son muy comparables; a las 24 horas, se observa que los HAC con el residuo de mármol y filler calizo presentan valores superiores al HAC-CEMII. A partir de entonces, el HAC-PM y HAC-CEMII presentan similar evolución hasta los 7 días aproximadamente, observándose valores ligeramente superiores en el caso del HACFC hasta dicha edad. Finalmente, a los 28 días el HACPM se encuentra $1 \mathrm{MPa}$ por encima del HAC-FC. Si bien el HAC-CEMII presenta inicialmente un comportamiento prácticamente equivalente a los HAC con filler adicionado, dicho hormigón presenta valores en torno a un $20 \%$ superior a los otros dos hormigones a la edad de 28 días.

Dado que contenidos y finuras equivalentes de clinker portland en las mezclas darían lugar a resistencias equiparables, fijos los demás componentes y sus proporciones, la diferencia de resistencia a los 28 días podría deberse,

\subsection{Compressive Strength}

Table 3 shows the compressive strength development up to an age of 28 days for the three SCC. The responses of the three types of concrete are highly comparable; after 24 hours, it can be observed that SCC with marble waste and limestone filler show higher values than SCCCEMII. After which, SCC-MP and SCC-CEMII show a similar evolution up to the 7th day, approximately; however, in the case of the SCC-LF larger values of strength where observed. Finally, at day 28, SCC-MP is 1 MPa above the SCC-LF and although the SCC-CEMII shows an initial behavior practically equivalent to the SCC with added filler, that concrete shows values around $20 \%$ higher than the other two types of concrete at 28 days.

Since equal contents and fineness of Portland clinker in the mixtures would produce comparable strength, while the rest of the components and their proportions are fixed, the difference in strength at 28 days could be 
Tabla 3 / Table 3

Evolución de la resistencia a compresión en el tiempo. Compressive strength development.

\begin{tabular}{|c|c|c|c|}
\hline Hormigón / Concrete & $\mathbf{f}_{\mathbf{c}} \mathbf{2 4}$ horas / hours (MPa) & $\mathbf{f}_{\mathrm{c}} \mathbf{7}$ días / days $(\mathrm{MPa})$ & $\mathbf{f}_{\mathrm{c}} \mathbf{2 8}$ días / days $(\mathrm{MPa})$ \\
\hline HAC-FC & 24.7 & 42.2 & 43.5 \\
\hline HAC-CEMII & 21.1 & 37.4 & 52.9 \\
\hline HAC-PM & 23.9 & $41.2^{*}$ & 44.6 \\
\hline
\end{tabular}

* Valor obtenido a la edad de 11 días / Value at 11 days.

eventualmente, a un menor contenido de caliza en el CEM II/B-L 32,5 N (mayor contenido de clinker), dado el posible rango de variación especificado anteriormente; 21-35\%.

Finalmente, cabe notar los convenientes valores de resistencia a compresión para un contenido de cemento de $398 \mathrm{~kg}$ (clinker en el caso del CEMII/B-L 32,5 N) y una relación a/c efectiva igual a 0,45.

\section{CONCLUSIONES}

Este trabajo ha presentado un estudio comparativo de propiedades reológicas, físicas y mecánicas de hormigones autocompactantes elaborados con diferentes tipos de finos minerales, o fillers.

El estudio se ha dividido en dos fases o escalas; la evaluación de las propiedades reológicas a nivel de la pasta cementícea y el posterior diseño y caracterización en estado fresco y endurecido de los HAC elaborados con dichas pastas.

A nivel pasta cementícea, se ha observado un comportamiento muy similar de aquellas elaboradas con un $100 \%$ de CEM I 52,5 R (P-CEM I), respecto a las pastas en las que se reemplazó un $30 \%$ de dicho cemento por residuo del corte de mármol (P-PM), y aquellas las elaboradas con el 100\% de CEM II/B-L 32,5 N (P-CEM II). Sin embargo, se evidencia un ligero aumento del tiempo de flujo (menor fluidez) en el caso de la pasta que contiene un $70 \%$ de CEM I 52,5 R + 30\% de filler calizo (P-FC).

Respecto a la demanda de aditivo superplastificante, se ha observado que el punto de saturación de dicho aditivo está en el orden del 0,50\% para las pastas P-CEM I y P-PM, 0,75\% para la pasta P-CEM II, y en torno al 1,00\% para la pasta P-FC.

Del comportamiento observado no se evidencian importantes pérdidas de fluidez durante las primeras dos horas posteriores a la fabricación, lo que cobra especial importancia práctica principalmente en el caso del HAC preparado donde, en general, se requiere asegurar un lapso de al menos 90 minutos durante los cuales deben mantenerse las condiciones de autocompactabilidad. due to a lower content of limestone in the CEM II/B-L $32.5 \mathrm{~N}$ (higher clinker content) leading to the possible variation rate previously specified; $21-35 \%$.

Finally, it is important to highlight that the compressive strength results obtained are suitable values for a concrete with a cement content of $398 \mathrm{~kg}$ (clinker in the case of CEMII/B-L $32.5 \mathrm{~N}$ ) and with an effective $\mathrm{w} / \mathrm{c}$ ratio of 0.45 .

\section{CONCLUSIONS}

This paper presented a comparative study of the rheological, physical, and mechanical properties of self-compacting concretes made with different types of fine minerals or fillers.

The study was divided into two stages or scales: the evaluation of rheological properties at a cementitious paste level, and the subsequent design and characterization of fresh and hardened state properties of the SCC made with the studied pastes.

Cementitious paste with $100 \%$ CEM I 52.5 R (P-CEM I), shows a similar behavior to those made in relation to the pastes where $30 \%$ of said cement was replaced by marble cutting waste (P-MP), and those made with $100 \%$ CEM II/B-L $32.5 \mathrm{~N}$ (P-CEM II). However, there was a small increase in the flow time (less fluidity) in the case of the paste with $70 \%$ of CEM I $52.5 R+30 \%$ of limestone filler (P-LF).

Regarding the amount of superplasticizer admixture required to achieve the saturation point of said additive, it was found $0.50 \%$ was required for the P-CEM I and $P$ MP pastes, $0.75 \%$ for the P-CEM II paste, and around $1.00 \%$ for the $P$-LF paste.

The resulting behavior does not show relevant fluidity losses during the first two hours after mixing, which is especially important in practice, in the case of ready-mix concrete, where generally requires a minimum time of at least 90 minutes is required, during which the selfcompactibility conditions must be maintained. 
De esta manera, se observa que el empleo del residuo del corte de mármol como filler no afecta la demanda de aditivo ni el tiempo abierto del mismo, despejando las dudas respecto a las posibles incompatibilidades por efectos contrarios con los aditivos floculantes presentes en el polvo de mármol.

A escala hormigón, comparando los HAC elaborados con filler calizo o polvo de mármol (HAC-FC y HAC-PM respectivamente), se observa una significativa ganancia de fluidez en el caso del HAC-PM, para la misma dosis de superplastificante. En términos reológicos, si se considera a los parámetros $D_{f}$ y $T_{V}$ como medidas indirectas de los parámetros de tensión umbral y viscosidad plástica respectivamente, se puede observar que el HAC-PM presentaría menores valores de estos parámetros. En términos generales, los tres HAC alcanzan combinaciones adecuadas; una baja tensión umbral (mayor fluidez) y una moderada viscosidad (que evite la segregación).

La evaluación de la retracción total hasta la edad de 28 días (después de 7 días de curado en cámara húmeda) permite observar un comportamiento prácticamente análogo para los tres HAC estudiados.

La evolución en el tiempo de la resistencia a compresión $\left(f_{c}\right)$ presenta respuestas muy comparables entre los tres HAC estudiados; hasta aproximadamente la primera semana, se observa que los HAC-FC y HAC-PM presentan valores de $\mathrm{f}_{\mathrm{c}}$ prácticamente equivalentes y superiores al HAC-CEMII. A partir de entonces, las medidas de $\mathrm{f}_{\mathrm{C}}$ a 28 días indican una clara recuperación del HACCEMII, con valores superiores a dicha edad; $9 \mathrm{MPa}$ mayores en promedio, lo cual se atribuye eventualmente, a un mayor contenido de clinker que el considerado en el CEM II utilizado.

De esta manera, considerando los resultados de los estudios realizados a nivel pasta y hormigón, que abarcan propiedades de gran importancia práctica, puede concluirse que los lodos generados como residuo en la industria del corte de mármol, representan un filler adecuado para su uso en hormigones autocompactantes. Este hecho representa una ventaja por partida doble; por un lado, se está dando uso a un residuo que, aunque prácticamente inerte, debe trasladarse a un vertedero, con el coste que ello representa. Por otro lado, el uso del polvo de mármol para alcanzar el volumen de pasta cementícea requerido en las mezclas de HAC evitaría que ello se consiguiera a partir de un aumento del contenido de cemento, por ejemplo, en situaciones donde no hay disponibilidad de fillers, con las ventajas medioambientales que ello conlleva.
In this way, it is observed that the use of the marble cutting waste as filler does not affect the demand of admixture nor its maximum or minimum open time, clearing up any questions about possible incompatibilities due to negative or collateral effects with the flocculating admixture present in the marble dust.

At the concrete scale, by comparing the SCC made with limestone filler and marble dust (SCC-LF and SCC-MP, respectively), there is a significant gain of fluidity in the case of SCC-MP, for the same dosage of superplasticizer. In rheological terms, if the $D_{f}$ and $T_{v}$ parameters are considered as indirect measurements of yield stress and viscosity, respectively, it is evident that SCC-MP would show lower values of these parameters. In broad terms, the three SCC reach appropriate combinations, a low yield stress (more fluidity) and moderate viscosity (to avoid segregation).

Total shrinkage evaluation until the 28 day (after 7 curing days in the fog room) shows a similar behavior for the three analyzed SCC.

The compressive strength development $\left(f_{c}\right)$ shows similar response among the three analyzed SCC; up to an age approximality 7 days, SCC-LF and SCC-MP showed $f_{C}$ values practically equivalent and higher than SCC-CEMII. From that point, $f_{C}$ measures at 28 days show a clear recovery of SCC-CEMII, with higher values at that age; $9 \mathrm{MPa}$ higher in average, which is eventually attributed to a greater content of clinker than the one estimated in the CEM II used.

Ultimately, considering the results of the studies performed at a paste and concrete level, which include properties with great practical importance can be concluded that the slurry generated as waste in the marble cutting industry represent an appropriate filler to be used in self-compacting concretes. This represents a twofold advantage. On the one hand, using a waste that, although practically inert, must be moved to a dump site with the corresponding costs. On the other, the use of marble powder to achieve the volume of cementitious paste required by SCC mixtures would prevent increasing the content of cement to obtain the self-compacting properties, for example, in situations where there are no fillers available with the corresponding environmental advantages. 


\section{AGRADECIMIENTOS}

Los autores agradecen el apoyo brindado por el Ministerio de Educación y Ciencia a través del proyecto de investigación "Habitat 2030. Materiales y componentes" (PSS 11-2005, PSE-380000-2006-4, PSE-380000-20071), la ayuda de la Doctora Celeste Torrijos durante la ejecución del programa experimental, y el soporte del personal del Laboratorio de Tecnología de Estructuras de la Universitat Politècnica de Catalunya, donde el trabajo fue realizado. Asimismo, se agradece el apoyo económico al programa de mejoramiento al profesorado PROMEP/103.5/03/2552 y $103.5 / 05 / 226$.

\section{ACKNOWLEDGEMENTS}

The authors would like to thank the grant given by the Spanish Ministry of Education and Science through the "Habitat 2030. Materials and Components" Research Project (PSS 11-2005, PSE-380000-2006-4, PSE-3800002007-1); the assistance of Dr. Celeste Torrijos throughout the completion of the experimental program, and the support of the staff of the Structural Technology Laboratory of the Universitat Politècnica de Catalunya, where the work was carried out. Also, the authors thank the economical support given by the Teachers Development Program, PROMEP/103.5/03/2552 and 103.5/05/226.

\section{BIBLIOGRAFÍA / BIBLIOGRAPHY}

(1) Vázquez, E.; Hendriks, Ch. F. y Janssen, G. M. T. (eds.). Proc. RILEM International Conference on "The Use of Recycled Materials in Buildings and Structures", Barcelona, Spain (2004).

(2) Malhotra, V. M. (ed.). Proc. Eighth CANMET/ACI International Conference on "Fly Ash, Silica Fume, Slag, and Natural Pozzolans in Concrete", Las Vegas, USA (2004).

(3) Gettu, R. (ed.): Proc. Workshop. "Desarrollo Sostenible del Cemento y del Hormigón", Barcelona, Spain (2002).

(4) El Mundo - Castellón al Día - 07/03/2003. "El residuo del mármol como materia prima" (2003).

(5) Freire, A. S. E.; Motta, J. F. M.: "Potencialidades para o aproveitamento económico de rejeito de serragem de granite". Rochas de qualidade, São Pablo, vol. 16, no 123, pp. 98-108 (1995).

(6) Santos Ruiz, J.: "Estudio para tratar de identificar posibles aplicaciones industriales para los residuos generados en el proceso de corte y elaboración de piedra natural, en concreto del mármol, analizando su viabilidad técnica y económica", Proyecto Final de Carrera, Universitat Politècnica de Catalunya (2004). http://hdl.handle.net/2099.1/3877

(7) Calmon, J. L.; Moratti, M.; Moraes, S.; Cenci, D.: "Self-compacting concrete using marble and granite sawing wastes as filler", Proc. The 2005 World Sustainable Building Conference, Tokyo, Japón (2005).

(8) Alyamaç, K. E.; Ince, R.: (2008). "A preliminary concrete mix design for SCC with marble powders", Constr. Build. Mater., vol. 23, I.3 (2009), pp. 1201-1210.

(9) Workshop on "Gainful utilization of marbel slurry and other stone waste", Jaipur, India, http://www.cdos-india.com

(10) Okamura, H.: "2Self-Compacting High-Performance Concrete", Concr. Intnl., vol. 19, no 7 (1997), pp. 50-54.

(11) Okamura, H.; Ozawa, K.; Ouchi, M.: "Self-Compacting Concrete", Structural Concrete, vol. 1, no 1, (2000), pp. 3-7.

(12) ACHE - Asociación Científico-Técnica del Hormigón Estructural (2008) Monografía "Hormigón autocompactante: Diseño y Aplicación".

(13) Péra, J.; Husson, S.; Guilhot, B.: "Influence of finely ground limestone on cement hydration". Cem. Concr. Compos., 21 (1999), pp. 99-105.

(14) Bonavetti, V.; Donza, H.; Menéndez, G.; Cabrera, O.; Irassar, E. F.: "Limestone filler cement in low w/c concrete: A rational use of energy". Cem. Concr. Res., 33 (2003), pp. 865-871.

(15) Bosiljkov, V. B.: "SCC mixes with poorly graded aggregate and high volume of limestone filler". Cem. Concr. Res., 33 (2003), pp. 1279-1286.

(16) Bédérina, M.; Khenfer, M. M.; Dheilly, R. M.; Quéneudec, M.: "Reuse of local sand: effect of limestone filler proportion on the rheological and mechanical properties of different sand concretes". Cem. Concr. Res., vol. 35 (2005), pp. 1172-1179.

(17) Corinaldesi, V.; Moriconi, G.; Naik, T. R.: "Characterization of marble powder for its use in mortar and concrete", CANMET/ACI/JCI International Symposium on Sustainable Development of Cement, Concrete, and Concrete Structures, Toronto, Canada (2005). http://www.uwm.edu/Dept/CBU/report/2005reports.html

(18) Binici, H.; Kaplan, H.; Yilmaz, S.: "Influence of marble and limestone dusts as additives on some mechanical properties of concrete", Scient. Res. Ess. vol. 2, no 9 (2007), pp. 372-379. http://www.academicjournals.org/SRE

(19) Zhu, W.; Gibbs, J. C.: "Use of different limestone and chalk powders in self-compacting concrete". Cem. Concr. Res., vol. 35, no 8 (2005), pp. 1457-1650.

(20) Correia Gomes, P. C.; Monteiro Lisboa, E.; Barboza de Lima, F.; Ramos Barboza, A. S.: "Obtención de hormigón autocompactable utilizando residuo de la industria de corte de bloques de mármol y granito", Proceedings Simposio fib "El Hormigón Estructural y el Transcurso del Tiempo", Eds. A. DiMaio y C. Zega, La Plata, Argentina (2005).

(21) Topçu, I. B.; Bilir, T.; Uygunoglu, T.: "Effect of waste marble dust content as filler on properties", Constr. Build. Mater., vol. 23, I.5 (2008), pp. 1947-1953. 
(22) Nehdi, M.; Pardhan, M.; Koshowski, S.: "Durability of self-consolidating concrete incorporation high-volume replacement composite cements". Cem. Concr. Res., vol. 34, no 11 (2004), pp. 2103-2112.

(23) Gupta, S.; Pandey, J. S.; Palla, A. K.; Nema, A. K.: "Utilization of Marble Powder in Self Compacting Concrete", Workshop on gainful utilization of marbel slurry and other stone waste, Jaipur, India (2008). http://www.cdos-india.com

(24) Girbés, I.; Martí, P.; Manzanedo, B.; Granizo, M. L.; Pérez, V.: "Propiedades reológicas y mecánicas de hormigones autocompactantes que incorporan lodos de corte de mármol", Proc. 1er Cong. Español sobre Hormigón Autocompactante, Eds. B. Barragán, A. Pacios y P. Serna, Valencia, España (2008).

(25) UNE-EN 445 (1996), "Lechadas para Tendones de Pretensado. Métodos de Ensayo," CEN, 12 pp.

(26) Kantro, D. L.: "Influence of Water Reducing Admixtures on Properties of Cement Paste - A Miniature Slump Test", Cem. Conc. Aggr., vol. 2 (1980), pp. 95-102.

(27) Correia Gomes, P. C.: "Optimization and Characterization of High-Strength Self-Compacting Concrete", Tesis Doctoral, Universitat Politècnica de Catalunya (2002).

(28) Gettu, R.; Izquierdo, J.; Correia Gomes, P. C.; Josa, A.: "Development of High-Strength Self-Compacting Concrete with Fly Ash: A four-step experimental methodology", Proc. 27th Conf. on Our World in Concrete \& Structures, CI-Premier Pte. Ltd., Eds. C.T. Tam, D.W.S. Ho, P. Paramasivam y T.H. Tan, Singapore (2002), pp. 217-224.

(29) ASTM (1992), "Standard Test Method for Unit Weight and Voids in Aggregate", C29/29M-92.

(30) UNE 83361 (2007). Hormigón autocompactante. Caracterización de la fluidez. Ensayo del escurrimiento.

(31) UNE 83362 (2007). Hormigón autocompactante. Caracterización de la fluidez en presencia de barras. Ensayo del escurrimiento con el anillo japonés.

(32) UNE 83364 (2007). Hormigón autocompactante. Determinación del tiempo de flujo. Ensayo del embudo en V.

(33) Ferraris, C. F.; Obla, K. H.; Hill, R.: "The influence of mineral admixtures on the rheology of cement paste and concrete", Cem. Conc. Res., vol. 31, no 2 (2001), pp. 245-255.

(34) Le Roy, R.; Roussel, N.: "The marsh cone as a viscometer: Theoretical analysis and practical limits", Mat. Struc. (2005), vol. 38, no 1.

(35) Wallevik, J. E.: "Relationship between the Bingham parameters and slump" Cem. Conc. Res., vol. 36 (2006), pp. $1214-1221$.

(36) Zerbino, R.; Barragán, B.; García, T.; Agulló, L.; Gettu, R.: "Efectos de la temperatura sobre los parámetros reológicos y propiedades ingenieriles del hormigón autocompactante", Proc. 1er Cong. Español sobre Hormigón Autocompactante, Eds. B. Barragán, A. Pacios y P. Serna, Valencia, España (2008). 